(c) Коломійчук Н.О., 2021

doi: 10.37321/nefrology.2021.28-06

УДК: 616:002-06

\title{
МІКРОСКОПІЧНИЙ ПОЛІАНГІЇТ І УРАЖЕННЯ НИРОК
}

\author{
КОЛОМІЙЧУК Н.О. \\ КНП «Київський міський центр нефрології та діалізу» \\ Київ, Україна
}

Резюме

Вступ. Мікроскопічний поліангіїт (МПА) зустрічається рідко (приблизно 13-19 випадків на мільйон населення). МПА - захворювання неясного ґенезу, асоційоване з виробленням антитіл до цитоплазми нейтрофілів і характеризується поєднаним запальним ураженням декількох органів, найчастіше легень і нирок, в основі якого лежить васкуліт дрібних судин без формування гранульом.

Мета. Описати клінічні прояви мікроскопічного поліангіїту з ураженням легень (пневмоніт) і нирок (гломерулонефрит), проаналізувати динаміку лабораторно-інструментальних показників у пацієнта зі швидким прогресуванням ниркової недостатності.

Матеріали і методи. Огляд сучасних та зарубіжних джерел, аналіз та обговорення конкретного клінічного випадку; методики - опис, аналіз, реферування.

Результати та їх обговорення. Враховуючи рецидивуючі поліморфні висипання на передній поверхні стегон, грудної клітки у вигляді “декольте”, розгинальних поверхнях верхніх кінцівок, що супроводжувались (дані амбулаторної карти) збільшенням ШОЕ, СРБ, ЦІК, лімфоцитопенією; позитивний ефект від лікування (у дерматологів) глюкокортикоїдами; суглобовий синдром (олігоартралгії з включенням крупних суглобів, дрібних суглобів кистей); лихоманку; лімфоаденопатію (збільшення підщелепних, шийних лімфатичних вузлів); ураження нирок (наростання рівнів сечовини, креатиніну, гематурія, протеїнурія, циліндрурія); ураження легень (пневмоніт, легенева недостатність), необхідно проведення диференційної діагностики між СЧВ, захворюванням крові та системними васкулітами (синдром Гудпасчера). Наявність атрофічного риніту, виражені запальні зміни в аналізах крові, позитивну відповідь на лікування глюкокортикоїдами, підвищені рівні P-ANCA дозволили діагностувати Мікроскопічний поліангіїт, підгострий перебіг, III ст. активності, з ураженням нирок (швидко прогресуючий гломерулонефрит, сечовий синдром, гематуричний компонент, артеріальна гіпертензія І ст.; гостра ниркова недостатність від 27.03.07р., стадія відновлення діурезу); легенів (пульмоніт, ЛН II-ІІІ ст.); верхніх дихальних шляхів (атрофічний риніт); суглобів (артралгії, ФНС 0 ст.); шкіри (хронічна рецидивуюча кропив янка); серозних оболонок (плеврит, перикардит); P-ANCA позитивний.

Висновки. МПА - мультидисциплінарна проблема. Своєчасна діагностика МПА та адекватне лікування у пацієнтів з ураженням нирок може сповільнити прогресування ниркової недостатності.

Ключові слова: мікроскопічний поліангіїт, нирки, легені, шкіра, діагностика, лікування.

Вступ. Мікроскопічний поліангіїт (МПА) зустрічається рідко (приблизно 13-19 випадків на мільйон населення). МПА - захворювання неясного ґенезу, асоційоване з виробленням антитіл до цитоплазми нейтрофілів і характеризується поєднаним запальним ураженням декількох органів, найчастіше легень і нирок, в основі якого лежить васкуліт дрібних судин без формування гранульом [1], відноситься до АНЦА-асоційованих васкулітів.

Мета. Описати клінічні прояви мікроскопічного поліангіїту з ураженням легень (пневмоніт) і нирок (гломерулонефрит), проаналізувати динаміку лабораторно-інструментальних показників у пацієнта зі швидким прогресуванням ниркової недостатності.
Матеріали і методи. Огляд сучасних та зарубіжних джерел, аналіз та обговорення конкретного клінічного випадку; методики - опис, аналіз, ресерування.

Клінічний приклад. Хвора М., 1954 р.н., пенсіонерка. Поступила у відділення нефрології 27.03.17 р. зі скаргами на болі в попереку справа та зліва, виражену загальну слабкість, втрату апетиту, нудоту, періодичні болі в суглобах (плечових, суглобах кистей), підвищення температури тіла до $38^{\circ} \mathrm{C}$, закладеність носу, слизові виділення з носу, задишку при фізичному навантаженні, сухий кашель.

Анамнез захворювання: вище описані скарги турбують хвору 3-4 дні, зі слів хворої хронічний пієлонефрит 3-4 роки, хворіє на хро- 
нічну кропив янку з 1999 р. (останнє загострення 3 тижні тому). Відмічає періодичне підвищення артеріального тиску до 150/90 мм.рт.ст., (гіпотензивні препарати на приймала). Аутоімунний тиреоїдит з 2003 р., хронічний холецистит, хронічний холангіт, рефлюкс-езофагіт, рефлюксгастрит з субатрофією слизової, фолікулярний бульбіт .

Загальний аналіз крові :

$\begin{array}{llcccc}\text { WBC } & \text { RBC } & \text { HGB } & \text { HCT } & \text { PLT } & \text { шOE } \\ 5,9 & 3,3 & 93 & 25,4 & 203 & 60\end{array}$

Лейкоцитарна формула

мієл.

1

1

Загальний аналіз сечі:

Пит. вага

$$
\text { Білок }
$$

Лейкоцити

1010

$$
0,22
$$

\section{Біохімічне дослідження крові :}

Альбумін

Загальний білок 73

Глюкоза

Сечовина 11,1

Сечова кислота 336

Креатинін 201

Загальний білірубін

ACT 35

АлТ 35

Калій

Натрій 144

Холестерин

\section{Коагулограма :}

Фібрин

Фібриноген

Активований час рекальцифікації

Протромбіновий час

Бета-нафталовий тест

Етаноловий тест

\section{Гострофазові показники :}

Антистрептолізин-О - 200 мо/мл С-реактивний білок - 192 мг/л

Ревматоїдний фактор - негативний

Рентгенографія легень: Заключення: двобічна нижньодольова плевропневмонія.

\begin{tabular}{llcc}
\multicolumn{1}{c}{ Еритроцити } & \multicolumn{1}{c}{ Епітелій } & Слиз & Бактерії \\
До 20 (змінені & $\begin{array}{l}\text { Плоский } \\
\text { та незмін) }\end{array}$ & + & + \\
небагато & + & +
\end{tabular}

$\begin{array}{cc}\boldsymbol{\pi} & \mathbf{M} \\ 15 & 4\end{array}$

4

Попередній діагноз: враховуючи скарги (болі в попереку, підвищення температури тіла, загальну слабкість, нудоту, втрату апетиту, задишку, сухий кашель), анамнез захворювання (хронічний пієлонефрит 3-4 роки), об`єктивні дані (крепітуючі хрипи в нижніх відділах легень з обох сторін, позитивний симптом Пастернацького 3 обох сторін), лабораторні дані. Поставлений діагноз: Гостра ниркова недостатність невстановленого ґенезу. Хронічний пієлонефрит в стадії загострення. Позагоспітальна двобічна нижньодольова пневмонія.

Призначене лікування: цесазолін 1,0 2 рази на день в/м (після отримання бак. посіву харкотиння, згідно чутливості був призначений цефотаксим 1,0 2 рази на день та ципрофлоксацин 500 мг 2 рази на день), флуконазол 100 мг 1 раз на добу, лазолван 1 таб. 3 рази на добу, гепарин за схемою, канефрон 2 таб. 3 рази на день.

УЗД органів черевної порожнини та нирок: печінка не збільшена, структура не змінена, ехогенність нормальна, жовчний міхур не деформований, стінка не потовщена, конкременти не виявлені, підшлункова залоза та селезінка без особливостей, права нирка $107 * 47$ мм, паренхіма 17-18 мм, ехо структура паренхіми змінена вогнищево - в нижньому сегменті кіста 20 мм, порожнинна система не розширена, конкременти не виявлені, ліва нирка 119*49 мм, паренхіма 1718 мм, ехо структура паренхіми не змінена, порожнинна система не розширена, конкременти не виявлені.

Ехокардіографія: корінь аорти - 2,8 см, ліве передсердя $-2,94^{*} 6,9$ см, правий шлуночок $-2,0$ см, нижня порожниста вена - 1,56 см, легенева гіпертензія - $30 \mathrm{mmHg}$, КДО - 93, КСО - 39, ФВ - 59\%, МШП - 1,15 см, задня стінка $-1,15$ см. Висновок: Сепарація листків перикарду. Атеро- 
склероз аорти. Помірна кількість рідини в правій плевральній порожнині.

Динаміка показників функції нирок:

\begin{tabular}{|l|c|c|c|c|c|c|c|}
\hline Сечовина & 11,1 & 15,6 & 16,5 & 17,6 & 25,7 & 41,9 & 60,3 \\
\hline Креатинін & 201 & 346 & 402 & 666 & 814 & 826 & 908 \\
\hline Калій & 3,7 & 3,4 & 3,4 & 2,6 & 3,1 & 3,0 & 3,6 \\
\hline Натрій & 144 & 140 & 140 & 135 & 137 & 136 & 137 \\
\hline HGB & 93 & 86 & 83 & 74 & 70 & 65 & 58 \\
\hline WBC & 5,9 & 7,4 & 8,2 & 7,9 & 6,5 & 6,0 & 8,9 \\
\hline ШOE & 60 & 68 & 60 & 65 & 78 & 78 & 79 \\
\hline
\end{tabular}

Враховуючи прогресивне збільшення рівнів сечовини та креатиніну, було встановлено двох-

одовий підключичний катетер та розпочато лікування гемодіалізом.
Консультація отоларинголога. Діагноз: хронічний субатрофічний риніт, двосторонній тубо отит. Гострий лівобічний катаральний гайморит.

Динаміка діурезу та добової протеїнурії:

\begin{tabular}{|l|c|c|c|c|c|c|}
\hline Добовий діурез & 1,2 & 1,6 & 1,5 & 1,5 & 1,8 & 1,5 \\
\hline Добова протеїнурія & 0,109 & & 0,108 & 0,973 & & 0,295 \\
\hline
\end{tabular}

Аналізи сечі:

Загальний аналіз - гематурія (до 20-30 в п/3, змінені та малозмінені); циліндрурія - гіалінові, зернисті, воскоподібні; лейкоцитурія до 20 в п/3.

Аналіз сечі за Нечипоренко - лейкоцити в межах норми, еритроцити до 200.000, циліндри до 38 зернистих, 2 гіалінових, 3 воскоподібних.

Добова протеїнурія до 0,973 г/добу.

Рентгенографія легень: пульмоніт, з ознаками базального бронхіту, виражені плевроперикардіальні спайки зліва. Множинні перибронхіальні стовщення, на фоні переднього відділу V ребра справа відмічається невеликої інтенсивності кругла тінь до 1 см. Рекомендовано: КТ легень для виключення “М” процесу.

\section{КT легень:}

Серце та судини без патологічних особливостей. Просвіти трахеї та бронхів збережені. Паратрахеальні, трахеобронхіальні, біфуркаційні та бронхопульмональні лімфатичні вузли збільшеними не візуалізуються. В нижніх відділах легеневий малюнок посилений, деформований.

Диференційний діагноз: враховуючи рецидивуючі поліморфні висипання на передній поверхні стегон, грудної клітки у вигляді "декольте”, розгинальних поверхнях верхніх кінцівок, що супроводжувались (дані амбулаторної карти) збільшенням ШОЕ, СРБ, ЦІК, лімфоцитопенією; позитивний ефект від лікування (у дерматологів) глюкокортикоїдами; суглобовий синдром (олігоартралгії з включенням крупних суглобів, дрібних суглобів кистей); лихоманку; лімфоаденопатію (збільшення підщелепних, шийних лімфатичних вузлів); ураження нирок (наростання рівнів сечо-

\begin{tabular}{|c|c|}
\hline & \\
\hline 1,8 & 1,5 \\
\hline & 0,295 \\
\hline
\end{tabular}

, креатиніну, гематурія, протеїнурія, циліндрурія); ураження легень (пневмоніт, легенева недостатність), необхідно проведення диференційної діагностики між СЧВ, захворюванням крові та системними васкулітами (синдром Гудпасчера).

Рентгенографія черепу: не можна виключити мієломну хворобу.

Аналіз сечі на білок Бенс-Джонса - не виявлено.

Стернальна пункція: підвищена клітинність кісткового мозку.

Консультація гематолога: даних за системне захворювання крові немає.

Антинуклеарні АТ - негативні.

ААТ до дволанцюгової ДНК - 34,3 IU/ml (норма $<30,0)$

AT до базальної мембрани гломерул - 0,3 U/ $\mathrm{ml}(<7,00$ - негативні)

C-ANCA( цитоплазматичні нейтрофільні AT) негативні

P-ANCA (перинуклеарні нейтрофільні АТ) позитивні

АТ до мієлопероксидази - 45,6 U/ml (норма $<9,0 \mathrm{U} / \mathrm{ml})$

\section{Клінічний діагноз:}

Враховуючи минучий суглобовий синдром, ураження шкіри за типом кропив янки, епізоди еозинофілії (за даними амбулаторної карти), лихоманку, характер ураження нирок (швидкий розвиток ниркової недостатності з домінуючою гематурією в осаді, без артеріальної гіпертензії, нефротичного синдрому), ураження легень 
(пульмоніт з вираженою легеневою недостатністю), наявність атрофічного риніту, виражені запальні зміни в аналізах крові, позитивну відповідь на лікування глюкокортикоїдами, підвищені рівні P-ANCA, у хворої:

Мікроскопічний поліангіїт, підгострий перебіг, III ст. активності, з ураженням нирок (швидко прогресуючий гломерулонефрит, сечовий синдром, гематуричний компонент, артеріальна гіпертензія І ст.; гостра ниркова недостатність від 27.03.07 р., стадія відновлення діурезу); легенів (пульмоніт, ЛН II-ІІІ ст.); верхніх дихальних шляхів (атрофічний риніт); суглобів (артралгії, ФНС 0 ст.); шкіри (хронічна рецидивуюча кропив янка); се- розних оболонок (плеврит, перикардит); P-ANCA позитивний.

Призначене лікування: преднізолон 40 мг на добу, пульс-терапія циклофосфаном 1000 мг з 250 мг метіпреду, ловастатин 20 мг на ніч, омепразол 20 мг 2 рази на добу, аспаркам 1 таб. 3 рази на день, гепаринотерапія за схемою, курантил 50 мг 2 рази на день, сеанси гемодіалізу, переливання еритроцитарної маси.

В результаті лікування: нормалізувалась температура тіла, зменшилась загальна слабкість, покращився апетит, збільшився рівень гемоглобіну та еритроцитів, знизились рівні сечовини та креатиніну.

На момент виписки :

\begin{tabular}{|c|c|c|c|c|c|}
\hline \multicolumn{6}{|c|}{ Загальний аналіз крові } \\
\hline WBC & RBC & HGB & HCT & PLT & ШOE \\
\hline 4,0 & 3,36 & 101 & 29,1 & 200 & 27 \\
\hline \multicolumn{6}{|c|}{ Загальний аналіз сечі } \\
\hline Питома вага & Білок & Лейкоцити & $\begin{array}{l}\text { Еритроцити } \\
\text { (змінені) }\end{array}$ & $\begin{array}{l}\text { Циліндри } \\
\text { (зернисті) }\end{array}$ & $\begin{array}{c}\text { Епітелій } \\
\text { (плоский) }\end{array}$ \\
\hline 1005 & 0,19 & $10-12$ & $8-10$ & $1-3$ & $6-8$ \\
\hline \multicolumn{6}{|c|}{ Біохімічне дослідження крові } \\
\hline Альбумін & Загальний білок & Сечовина & Креатинін & Калій & Натрій \\
\hline 37 & 60 & 25 & 398 & 4,6 & 141 \\
\hline
\end{tabular}

Рекомендовано: зниження дози преднізолону до 30 мг, пульс терапія циклофосфаном 1000 мг 1 раз на місяць, омепразол 20 мг 2 рази на день, аспаркам 1 таб. 3 рази на день, варфарин 3,75 мг (контроль ПТІ кожні 2 тижні), ловастатин 20 мг на ніч, курантил 50 мг 2 рази на день, метопролол 25 мг 2 рази на день.

Обговорення: Патогенез МПА вивчений недостатньо, МПА вражає дрібні судини і $є$ слабоімунним захворюванням (тобто біопсія тканини не виявляє імуноглобулінових відкладень), схожий на гранулематоз з поліангіїтом (ГПА) і еозинофільний гранулематоз з поліангіїтом (ЕГПА), що відрізняє його від імунокомплексних васкулітів дрібних судин (наприклад, геморагічного васкуліту, пурпури Шенлейна-Геноха) і шкірного васкуліту дрібних судин. МПА зачіпає переважно дрібні судини (в тому числі капіляри і посткапілярні венули), на відміну від вузликового поліартериїту, який впливає на м'язові артерії середнього розміру.

Зазвичай спочатку виникає продромальний період, який мав місце у нашої пацієнтки - з загальними проявами, включаючи лихоманку, зниження маси тіла, міалгії і артралгії. Частота ураження нирок досягає 90\%. Виявляють гематурію, протеїнурію (іноді>3 г/добу), еритроцити. Якщо діагноз не встановлений і лікування не призна- чено, може швидко розвинутися ниркова недостатність (у нашої пацієнтки швидко прогресувала ниркова недостатність, що стало приводом переводу їі на ниркову замісну терапію - гемодіаліз). Приблизно у третини хворих на момент встановлення діагнозу зазначається пурпура. Можуть виникати інфаркти нігтьового ложа, іноді - ішемія пальців. У даному випадку мали місце рецидивуючі поліморфні висипання на передній поверхні стегон, грудної клітки у вигляді “декольте”, розгинальних поверхнях верхніх кінцівок, що супроводжувались збільшенням ШОЕ, СРБ, ЦІК, лімфоцитопенією. Наявність однобічного інфільтрату в легені на рентгенограмі грудної клітини може бути обумовлений альвеолярною кровотечею, хоча нам не вдалося достеменно встановити причину однобічного інфільтрату у конкретної хворої. При ураженні легенів може виникати альвеолярне кровотеча з подальшим легеневим фіброзом. Можуть виникати слабко виражені симптоми риніту і синуситу, а також носова кровотеча, але в разі важкого ураження верхніх дихальних шляхів більш імовірний діагноз гранулематоза з поліангіїтом. Болі в животі, нудота, блювота, діарея, кров в калі можуть бути першими проявами МПА. При ураженні нервової системи може розвинутися множинна мононевропатія (множинний мононеврит) з ураженням 
периферичних або черепно-мозкових нервів. Іноді виникають внутрішньомозковий крововилив, інфаркт, конвульсії, головні болі, пов'язані з церебральним васкулітом.

Висновки. Таким чином, МПА - мультидисциплінарна проблема. Своєчасна діагностика МПА та адекватне лікування у пацієнтів з ураженням нирок може сповільнити прогресування ниркової недостатності.

\section{PEЗЮME}

\section{МИКРОСКОПИЧЕСКИЙ ПОЛИАНГИИТ И ПОРАЖЕНИЕ ПОЧЕК}

Коломийчук H.A.

КНП «Киевский городской центр нефрологии и диализа» (Киев, Украина)

Введение. Микроскопический полиангиит (МПА) встречается редко (примерно 13-19 случаев на миллион населения). МПА - заболевание неясного генеза, ассоциированное с выработкой антител к цитоплазме нейтрофилов и характеризуется совмещенным воспалительным поражением нескольких органов, чаще всего легких и почек, в основе которого лежит васкулит мелких сосудов без формирования гранулем.

Цель. Описать клинические проявления при микроскопическом полиангиите с поражением легких (пневмонит) и почек (гломерулонефрит), проанализировать динамику лабораторно-инструментальных показателей у пациента с быстрым прогрессированием почечной недостаточности.

Материалы и методы. Обзор современных и зарубежных источников, анализ и обсуждение конкретного клинического случая: методики - описание, анализ, реферирование.

Результаты и их обсуждение. Учитывая рецидивирующие полиморфные высыпания на передней поверхности бедер, грудной клетки в виде «декольте», разгибательных поверхностях верхних конечностей, сопровождающиеся (данные амбулаторной карты) увеличением СОЭ, СРБ, ЦИК, лимфоцитопенией; положительный эффект от лечения (у дерматологов) ГКС; суставной синдром (олигоартралгии с включением крупных суставов, мелких суставов кистей); лихорадку; лимфоаденопатию (увеличение подчелюстных, шейных лимфатических узлов); поражения почек (нарастание уровня мочевины, креатинина, гематурия, протеинурия, цилиндрурия) поражения легких (пневмонит, легочная недостаточность), необходимо проведение дифференциальной диагностики между СКВ, заболеванием крови и системными васкулитами (синдром Гудпасчера). Наличие атрофического ринита, выраженные воспалительные изменения в анализах крови, положительный ответ на лечение ГКС, повышенные уровни P-ANCA позволили диагностировать Микроскопический полиангиит, подострое течение, III ст. активности, с поражением почек (быстропрогрессирующий гломерулонефрит, мочевой синдром, гематурический компонент, артериальная гипертензия I ст., острая почечная недостаточность от 27.03.07 г., стадия восстановления диуреза), легких (пульмонит, ЛН
II-III ст.), верхних дыхательных путей (атрофический ринит), суставов (артралгии, ФНС 0 ст.), кожи (хроническая рецидивирующая крапивница), серозных оболочек (плеврит, перикардит); P-ANCA положительный.

Выводы. МПА - мультидисциплинарная проблема. Своевременная диагностика МПА и адекватное лечение у пациентов с поражением почек может замедлить прогрессирование почечной недостаточности.

Ключевые слова: микроскопический полиангиит, почки, легкие, кожа, диагностика, лечение.

\section{SUMMARY}

\section{MICROSCOPIC POLYANGIITIS AND KIDNEY INFLAMMATION}

Kolomiichuk $N$

KNP «Kyiv City Center of Nephrology and Dialysis» (Kyiv, Ukraine)

Introduction. Microscopic polyangiitis (MPA) is rare (approximately 13-19 cases per million population). MPA is a disease of unclear genesis associated with the production of antibodies to the cytoplasm of neutrophils and is characterized by combined inflammatory lesions of several organs, most often the lungs and kidneys, which is based on vasculitis of small vessels without the formation of granulomas.

Goal. Describe the clinical manifestations of microscopic polyangiitis with lesions of the lungs (pneumonitis) and kidneys (glomerulonephritis), analyze the dynamics of laboratory and instrumental parameters in a patient with rapid progression of renal failure.

Materials and methods. Review of modern and foreign sources, analysis and discussion of a specific clinical case; methods - description, analysis, abstracting.

Results and discussion. Given the recurrent polymorphic rash on the anterior surface of the thighs, chest in the form of a "décolleté", extensor surfaces of the upper extremities, accompanied (ambulatory card data) by an increase in ESR, CRP, CEC, lymphocytopenia; positive effect from treatment (in dermatologists) of corticosteroids; joint syndrome (oligoarthralgia with the inclusion of large joints, small joints of the hands) fever; lymphadenopathy (enlargement of the submandibular, cervical lymph nodes); kidney damage (increase in urea, creatinine, hematuria, proteinuria, cylindruria) lung damage (pneumonitis, pulmonary insufficiency), it is necessary to conduct a differential diagnosis between SLE, blood disease and systemic vasculitis (Goodpasture's syndrome). The presence of atrophic rhinitis, pronounced inflammatory changes in blood tests, a positive response to treatment with corticosteroids, elevated levels of P-ANCA allowed to diagnose microscopic polyangiitis, subacute course, III st. activity, with kidney damage (rapidly progressing glomerulonephritis, urinary syndrome, hematuric component, arterial hypertension I in, acute renal failure from 27.03.07, stage of recovery of diuresis) lungs (pulmonitis, LN II-III st.) upper respiratory tract) joints (arthralgia, FTS 0 st.) skin (chronic recurrent urticaria) of serous membranes (pleurisy, pericarditis); P-ANCA is positive.

Key words: microscopic polyangiitis, kidneys, lungs, skin, diagnosis, treatment. 


\section{АВТОРСЬКА ДОВІДКА}

\section{Коломійчук Наталія}

\section{Олександрівна}

КНП «Київський міський центр

нефрології та діалізу», М. Київ,

завідуюча відділенням госпітальної

нефрології та діалізу №2

Адреса: вулиця Петра Запорожця, 26,

Київ, 02125

моб.: +380973509931

E-mail: tasha_2001@ukr.net

\section{Коломийчук Наталия} Александровна

КНП «Киевский городской центр нефрологии и диализа», г. Киев, заведующая отделением госпитальной нефрологии и диализа \#2

Адрес: ул. Петра Запорожца, 26,

Киев, 02125

моб.: +380973509931

E-mail: tasha_2001@ukr.net

\section{Kolomiichuk Nataliia}

KNE "Kyiv City Center of Nephrology and Dialysis", Kyiv, head of the department

Address: 26 Petro Zaporozhets Street, Kyiv, 02125

моб.: +380973509931

E-mail: tasha_2001@ukr.net 